\title{
DEBATING REAL INTEGRATED TERRITORIAL COOPERATION APPROACHES TO POST-2020 EU POLICIES: THE CHALLENGES ARISING FROM COVID-19 FROM THE PERSPECTIVE OF THE ASSOCIATION OF EUROPEAN BORDER REGIONS (AEBR)
}

\author{
Martín Guillermo Ramírez \\ Secretary-General \\ Association of European Border Regions \\ Anna-Mackenroth-Weg 49, D-12205 Berlin: Germany \\ m.guillermo@aebr.eu
}

\begin{abstract}
The European Union (EU) territorial development and cohesion have been supported by European institutions for decades, but they currently face a critical moment: the COVID-19 pandemic and European coordination gaps have to be added to previously-existing difficulties, such as the growing climate-related and demographic challenges, and the wave of Euroscepticism, nationalism and populism. Viruses do not recognise borders, but the EU is still divided between those thinking that the economy should prevail over politics and those thinking otherwise. European citizens living in border areas know very well that we need a common approach (and a stronger commitment) to the preservation of our values and rights, as well as to the definitive positioning of the EU as a global player. Integration starts at the bottom and moves across borders. The legacy of cohesion and territorial stability that the EU leaves for future generations will depend on how it protects and strengthens cross-border cooperation at this stage.
\end{abstract}

Keywords: cross-border cooperation, cross-border obstacles \& challenges, European Territorial Cooperation, ETC, European territorial integration, territorial cohesion.

\section{Introduction}

It is not easy to keep a focus on integrated territorial cooperation at a time when national priorities prevail over any European considerations. On the verge of a new European Union (EU) programming period dominated by reconstruction and recovery, many of us who are expected to offer an opinion about the future of territorial cooperation have to admit that we have rethought everything about ourselves during the pandemic, our discourse has changed at times, and above all, we have also had to reconsider our priorities. To illustrate this, I have made reference to the evolution over recent months of our organisation's top priority: the wellbeing of citizens living in border regions; while highlighting their role in the process of European integration. Much of this integration is taking place in a growing number of border areas crossed by many citizens daily 
for work, study, shopping, and a host of other activities. The normalisation of everyday relations across borders may be one of the most powerful images of the enormous coexistence effort we know as the EU, yet now we see how all of those achievements of decades of European integration can be removed or rescinded overnight by national decisions. Therefore, if we are talking seriously about EU integration, we still need an EU that guarantees the basic freedoms, holding coordinated mechanisms of control in case of an emergency, as well as a Common Foreign Policy and other common and joint services. A future that boosts and enhances territorial cooperation in general, and cross-border cooperation $(\mathrm{CBC})$ in particular, depends very much on the achievement of a certain level of integration that allows for the overcoming of the many legal and administrative obstacles (mainly at national level) that still do so much to regularly make CBC a mammoth task.

As I am not a researcher, this cannot be - and is not intended to be - an academic paper. However, I would like to share with academics in relevant fields a series of reflections I have been nurturing about where we are with territorial cooperation, how COVID-19 has affected CBC at the time when crucial decisions for the future are being discussed at European level, and how we can face both the near-future and the time beyond. These reflections are a juxtaposition of the experience of the Association of European Border Regions (AEBR) after almost fifty years in existence on the one hand, and what we went through during the first half of 2020 when so many things arose to affect the work of European border and cross-border regions.

Specifically, I have elaborated this paper following preparation of an article in Spanish for the online magazine of the European and Ibero-American Academy of Yuste Foundation at the end of the confinement (Guillermo Ramírez, 2020). I was asked by Yuste to describe how European integration is happening at its borders, as well as the variety of opportunities, risks and challenges that exist in these amazing territories. To that list, we now have to add the ones provoked by the current pandemic. I also reviewed the reports we have prepared regularly for our members on discussions regarding the upcoming Multiannual Financial Framework (MFF) and the Recovery Package, in particular between February and August 2020 (AEBR, 2020c, May 19, 2020d, August 3). It is still very impressive to realise how little we knew about the SARS-CoV-2 virus and COVID-19 in March 2020 and how little we still know now about the current pandemic's further consequences.

As of the end of February 2020, a great part of our continent was still seeing coronavirus as not really our business. Most members of AEBR (European border and cross-border regions) were stressing the need to communicate with the European institutions to express concerns as regards a possible reduction of funds for Cohesion Policy in the upcoming 2021-2027 programming period. The Commission, Parliament and Council were all discussing the future MFF at that time, with no agreement in sight, but with little hope of EU accounts (just over 1\% of the GDP of all member states) being increased.

But once our organisation's position had been drawn up and transmitted through the usual channels to the Commission services, we were faced from mid-March onwards with a situation in which a pandemic had been declared officially, and there was general closure of borders of the EU, including internally. Schengen had just disappeared, putting at ultimate risk that work of decades building trust, restoring good relations between neighbours, and eliminating prejudices across national borders.

The confinement imposed on most European territories passed with citizens and institutions alike keeping an anxious eye on increasing numbers of cases (and especially casualties), all the time awaiting the much-desired peak and subsequent decline. Peaks and plateaux did indeed come along, as well as tension and solidarity, information and disinformation, heroes and villains. De-confinement arrived in June, and many companies returned to business, even as others fell 
by the wayside. Critically-affected sectors such as tourism or culture were also moving gradually towards a slightly brighter future, but one that had to (and still must continue) to be characterised by uncertainty until such time as the expected vaccines arrive everywhere. Meanwhile, the EU ultimately came up with its response to the crisis - which was more firm than many would have expected (a Recovery Fund on top of the MFF to be spent in the coming 2-3 years, including a great share of grants, and a commitment to develop EU-own sources of financing). This commitment to European inter-territorial solidarity may in fact be one of the main milestones in the European construction, comparable to the Maastricht Treaty (EC, 1992) or the great enlargement of 2004. We must now take this opportunity to undertake certain unavoidable reforms: a transition to a more-sustainable model of development in many regions, a reduction of digital disparities and problems with access to public services in border areas, a solution for cross-border employment issues and so on. All these things have to be done in concert - meaning something beyond the mere agreement of EU member states one with another.

Nevertheless, the ambitious EU financial proposal on the table - which almost doubles the Union budget - has also highlighted certain ongoing differences between member states, precisely because they are nation-states and seemingly still find it difficult to comprehend the supranational scope of current challenges. If climate change, migratory phenomena, or the need to comply with the Sustainable Development Goals (SDGs) have not fully convinced some governments of the need for joint and effective action, perhaps this mutant coronavirus will at least help show how many threats ignore borders and other conventions that humans have come up with apparently for protection... very often in the face of 'ourselves'. It has become quite clear how joint and determined action is needed to arrest our planet's deterioration. We also need to preserve and strengthen the few global institutions that have managed to achieve particularly important goals for all. This would be the case for the World Health Organization, processes like the EU or the United Nations System, and others such as the African Union, the Central American Integration System, Mercosur or the Andean Community, the Union for the Mediterranean, and similar initiatives. All of these need strengthening if there is to be consolidation of common spaces for the construction of peace and democracy, respect for human rights and the rule of law, protection of the environment, development of clean energy and productive activities, a fight against hunger and extreme poverty, and provisioning of basic services for all. There is a growing global interrelationship, as this pandemic has revealed; and many multilateral agencies are in place. But there is also a sense of transparency being in short supply, with a lack of participation on the part of citizens who are increasingly well-informed (though also at far greater risk of succumbing to the abundance of information of all kinds). There is also a feeling that nation-states come to these multilateral initiatives, including the $\mathrm{EU}$, with the organisation's logo in their buttonholes, but their national agendas under their arms.

So, how can we consider the immediate future? And the less-immediate one? As I approach questions of this type, I always remember the book written almost twenty years ago in tandem by a former head of the Spanish Government and a famous journalist, which was entitled The future is no longer what it used to be (Cebrián \& González, 2001). Written in 2001 - but in fact published a few days before September $11^{\text {th }}$, it was even then possible for the co-authors to write that we were entering a time in which nothing would be easy to predict. 9/11 was obviously one of those days 'when everything changed', but it was followed by attacks in Tunis and Indonesia in 2002, as well as the crisis at the Dubrovka Theatre in Moscow; Casablanca and Istanbul in 2003; Madrid and Beslan in 2004; London, Sharm el-Sheik, Delhi and Amman in 2005, etc. There are also increasingly frequent natural disasters, political, social and financial instabilities, deep crises throughout much of the world after various non-solved troubles, and issues with the proliferation of populist, nation- 
alist and separatist feelings. These include the phenomenon that is Brexit, with its potential effects on the border of Ireland and Northern Ireland, meaning uncertainty just over twenty years on from the exemplary 'Good Friday Agreement'. If (outgoing) President Trump had fully had his way and completed the wall at the US border with Mexico, he would conversely have set a disastrous precedent - yet one that might even have been hailed by certain EU member states. If nationalism and populism progress, Euroscepticism will be consolidated. And if climatic and demographic change, the SDGs and the digital divide are not addressed, we will have no future.

So things did not look that good; yet in fact, the worst was yet to come.

In the following pages, I will try to offer an overview of the state of territorial cohesion in the EU from the point of view of the AEBR, as a network of border and cross-border regions. I will also reflect on current obstacles, achievements and challenges, as well as some measures already implemented, like the $b$-solutions project (see AEBR, 2017; 2020ab). The new challenges faced by border regions will also be dealt with, including COVID-19; as well as the reaction of the EU in the midst of the discussions on the budget for the next programming period. I will also reflect on territorial cohesion and cooperation within the new financial framework, without neglecting the issue of the importance of EU external frontiers, and the role of special cross-border operations such as the small project fund for people-to-people actions, and the European Groupings of Territorial Cooperation (EGTCS). I will then conclude briefly while leaving the field open for readers to arrive at their opinions as to the relevance of $\mathrm{CBC}$ for the future of Europe.

\section{Territorial cohesion and the AEBR}

EU territorial development and cohesion has been pushed forward by European institutions for many years, particularly via Interreg (EC, 1990) and further territorial programmes since 1990; and then by virtue of the Treaty of Maastricht and the establishment of the European Committee of the Regions (created in 1992 under the Treaty of Maastricht and established in 1994). This territorial approach has not been addressed exclusively to countries within the EU, but also to our neighbours (the so-called Pre-Accession and Neighbourhood countries). On the other hand, it has been extremely important to increase the involvement of local and regional authorities in European matters, and also to promote a deeper cohesion of territories across Europe - from the economic, social and territorial points of view. The AEBR has been involved in most of the advances relevant to European territorial cohesion.

The AEBR is one of Europe's oldest independent association of regions, founded in 1971 - and the only one dedicated to $C B C$ in most EU member states, the United Kingdom, EFTA countries, candidates for accession, the beneficiaries of the Neighbourhood Instrument and the Russian Federation. It has almost half a century of extensive theoretical and practical experience in all aspects of CBC, but also in interregional and transnational cooperation. Since the 1970s, the AEBR has had direct involvement in many initiatives at local, national, regional and European level, aimed at establishing more appropriate programming of territorial cooperation in general and CBC in particular. It has also been implicated in the elaboration of legal frameworks for cooperation between European local and regional authorities, among other regional-policy initiatives. Its focus on promoting public policies and capacity-building in European border and cross-border regions has made AEBR a relevant actor in the development of CBC programmes and projects. 
The main objective of the AEBR is to promote the interests of European border and cross-border regions:

- identifying their problems, opportunities, tasks and projects, explaining them and making them visible;

- representing their general interests to national and international parliaments, other authorities and institutions;

- initiating, supporting and coordinating their cooperation across Europe;

- exchanging experiences and information to formulate and coordinate common interests based on different problems and opportunities in border regions, and offering solutions;

- promoting $\mathrm{CBC}$ structures, projects and programmes;

- collaborating in the preparation of CBC events and other activities.

With a hundred members (border and cross-border regions) in more than thirty countries; and a database of contacts with several thousand entries, the network established by the AEBR has followed strategic development processes, cross-border programmes, projects and structures along most European borders, within and outside the EU. In addition to the areas within the 'old' EU, the Association worked with relevant institutions in the new member states during the years leading up to their accessions - to assist in the implementation of cross-border structures, programmes and projects. Currently, the AEBR also works alongside national and regional institutions at the EU's external borders, in the Russian Federation, Ukraine, Armenia, Turkey and other countries, following and supporting CBC development processes.

Furthermore, regular contacts have been made since 2000 with local, regional and national governments, as well as with intergovernmental institutions in Latin America, with the aim being to explain the process of European integration, the impact of EU Regional Policy and practical experience in $\mathrm{CBC}$ as a driving force for integration across international borders. Given the opportunity to exchange, as well as supply, information, there has also been very useful learning about the different initiatives pursued in Latin American countries to promote $C B C$ in what are very different circumstances, and to be in contact with most relevant actors. Similarly, the AEBR keeps open several channels of collaboration with various $\mathrm{CBC}$ initiatives in West Africa, while promoting some projects in the Near East and collaborating with the GIZ (the German Cooperation Agency) over certain initiatives in the Far East.

\section{Obstacles, achievements and 'traditional' challenges}

The development of $\mathrm{CBC}$ has faced a major obstacle from the outset, which is the combination of the concepts of the nation-state and the national sovereignty that goes with it. Fortunately, CBC has developed within the framework of the construction of a EU in which the member states have evolved when it comes to their way of conceiving of national sovereignty, and have moreover accepted the transfer of part of that sovereignty upwards, towards the EU level. On the other hand, in some countries more than others, there has also been a significant share of sovereignty downwards, thanks to processes of the devolution of competences to regional or municipal levels, often in line with the subsidiarity principle. All this has made it possible to adapt $C B C$ to existing possibilities, even as we go on facing asymmetries, imbalances, and differentials, as well as multiple obstacles, including those of a psychological nature (mainly relating to prejudices and stereotypes vis-à-vis the neighbour). 
Much progress has been made in recent years, particularly in the EU, and there are a number of regions that have made very good use of their opportunities. In fact, in the latest exercises to identify obstacles to CBC (Cross-Border Review ${ }^{1}, b$-solutions ${ }^{2}$ ), most of these have been found in those regions where cooperation is stronger, and vice versa. Some regions have not benefited or have not been able yet to open up the roads that their colleagues along the Rhine, in Scandinavia or in Ireland started off on several decades ago now. The history of CBC is marked by several milestones that have led to greater facilitation of cross-border relationships, the provision of stable resources, or the establishment of $\mathrm{CBC}$ structures. And the EU continues making progress with new proposals, such as the latest European Cross-Border Mechanism (ECBM; COM, 2018), as supported by the Parliament and the European Committee of the Regions, but not secured by the EU Council as yet. The ECBM would make it possible to repeal, in a given territory and under appropriate conditions, a provision causing an obstacle to $\mathrm{CBC}$; and would even allow the legislation of the neighbouring country to be applied where this is most appropriate to the resolving of a given problem. This would be a voluntary mechanism, but it still generates much suspicion among most EU member states. This also shows how much more needs to be done to create greater trust between states.

Regional and local authorities have done their homework, and quite well in my opinion. Involvement, commitment and political will can all be observed in many cross-border environments all over Europe. A vision prevails that development can only be achieved where there is collaboration with neighbours, overcoming the grievances, contempt and mistrust that are the fruit of centuries of conflict. This can be compared with African borders, many of which have divided ancestral communities since the pens of the colonial powers put to work at the Berlin Conference of 1884-1885 (Britannica, 2020), culminated in a map in 1914 very similar to the current one. African CBC has reformalised many relationships dating back to pre-colonial times, while European $\mathrm{CBC}$ has healed secular conflicts, including the Irish one, despite Brexit. But there are wounds which are not closed yet, and CBC still has a huge task to perform.

Main milestones in this bottom-up race of European border regions are considered to be the creation of the first Euroregions in the late fifties and the sixties, the Madrid Outline Convention in 1980, the Interreg Initiative in 1990 and the EGTCs in 2007. From the seventies on, the dozen AEBR founding euroregions drove the debate on the need to promote cooperation across national borders within the European Communities and among the Council of Europe (CoE) states; and to provide a regulatory framework for cross-border relations between sub-national public administrations. The CoE was very sensitive to these needs, thanks to various reports on pioneer cross-border territories, and the result was the Madrid Outline Convention (CoE, 1980). Many Euroregions were set up under this Convention, though the first had already been established in $1958^{3}$.

With the proliferation of structures, relationships and projects, a search for financing became necessary. But only with a programme adopted in 1989 and initiated in 1990 to compensate for the harmful effects of the Schengen Agreement, in particular the loss of jobs in customs and border controls, was there a decisive trigger to generalise CBC at the EU's internal borders, i.e. Interreg.

\footnotetext{
${ }^{1}$ The Cross-Border Review was a process of research and dialogue initiated by the European Commission's Directorate General for Regional and Urban Policy (DG REGIO) with stakeholders and national authorities, between July 2015 and February 2017, with a view to persisting challenges in border regions being responded to better (COM, 2015-2017).

${ }^{2} b$-solutions is an initiative promoted by the European Commission's DG REGIO and managed by the AEBR to identify legal and administrative obstacles to CBC; and to propose solutions (AEBR, 2017). This is one of the actions proposed in the Communication Boosting growth and cohesion in EU Border Regions (COM, 2017a).

${ }^{3}$ EUREGIO (DE/NL), with headquarters in Gronau (Westfalia, Germany), was the first euroregion ever. EUREGIO hosts AEBR's main office.
} 
Now in its thirtieth year, this no longer brings together just CBC Operational Programmes at the internal EU borders; but has also incorporated CBC programmes in candidate countries and those at the external frontiers. Over the years, several thousand cross-border projects have been sewing European borders together ${ }^{4}$. The next major milestone was the European Groupings of Territorial Cooperation (EGTCS), which in their initial version we wanted to call 'European Groupings of Cross-Border Cooperation'. This was also the result of strong demand by the regions organised in the AEBR: a legal instrument of public law to be incorporated into the acquis communautaire to further facilitate CBC. Since its adoption in 2006, 77 EGTCs have been set up. And the next milestone we would like to see is the abovementioned ECBM. This would mean a huge jump into a new concept of sovereignty by member states within the EU framework. Time will tell.

As for the remaining challenges, in addition to the final shape of the European budget for territorial cooperation in the coming period, there were also some outstanding issues to resolve in the proposing of regulations by the European Commission in spring 2018, on which both the European Parliament and the Committee of the Regions already expressed views as regards maritime cooperation, person-to-person projects, thematic concentration, co-financing rates, simplification of procedures, etc. Most of these issues have progressed quite well, looking at the Conclusions of the European Council on 21 July 2020, while others still had to be tuned better ${ }^{5}$.

On the other hand, despite the particular impact of the pandemic in some regions, territorial cohesion was not considered in the first proposals for a Recovery Package, even though there remained possibilities for this gap to be made good 6 . We must add other challenges to which border and cross-border regions are not strangers, such as adaptation to climate change, the need to move towards more sustainable energies and more comprehensive approaches to migratory phenomena, the rise of nationalist movements and the risk of border closures within the Schengen area, or the shielding of the EU's external borders, and other walls. We also have the imminent challenge of the effects of Brexit on the border of Ireland and other UK borders with the EU such as Calais-Dover and the Eurotunnel or Gibraltar. And we are not sure yet of the effects of the COVID 19 pandemic in the mid- and long-terms.

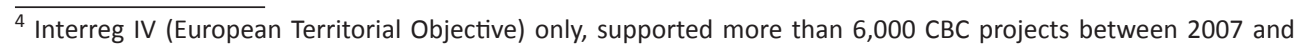
2013 (COM, 2020c).

${ }^{5}$ When reviewing this text before sending to print, EU Council of Member States, the Parliament and the Commission (the Trilogue) have already agreed on 2 December 2020 on the budget and regulations for Interreg $\mathrm{VI}$ (2021-2027), which includes $€ 5,800$ million for CBC programmes and projects (COM, 2020b). The total funding for CBC will also include national co-financing (20\% in the EU, $15 \%$ in outermost regions, and probably less in Neighbourhood and Pre-Accession countries) and, a very relevant newness, a general recommendation to take CBC into account in other policies such as healthcare and other public services, employment, transport, small and medium enterprises, etc., according to the European Territorial Agenda 2030, adopted during the German Presidency of the Council of the EU (TA2030, 2020).

${ }^{6}$ Finally, after a strong lobby by the European Committee of the Regions and the associations of local and regional authorities within the \#CohesionAlliance (CoR, 2018), and the particular commitment of the European Parliament, this was included in the discussions within the Trilogue in October and November 2020. On 10 December the Council has agreed the MFF for 2021-2027 and Next Generation EU (NGEU), the fund for reconstruction. React EU, one of the instruments within NGEU, will top up the funding of current Cohesion Policy programmes, including CBC ones under Interreg V (2014-2020). €1.6-2.6 billion will be allocated additionally to Interreg V programmes in 2021 (mostly) and 2022, while every action under React EU is eligible as of 1 February 2020 and can be implemented until the end of 2023 .
} 


\section{b-solutions}

As mentioned, the AEBR has the privilege to implement the $b$-solutions initiative, which has already delivered a major output. The first $b$-solution compendium (AEBR, 2020ab) contains all the findings gathered during the first two years of implementation of this pilot initiative commissioned by the European Commission's DG REGIO. The main objectives are to identify legal and administrative obstacles to CBC and to propose sustainable and replicable solutions. This is one of the actions proposed in the Commission's Communication on border regions (COM, 2017a) because, despite thirty years of Interreg and other instruments, legal or administrative obstacles still exist, and continue to harm actors and citizens living and operating across borders.

Within the framework of $b$-solutions, the AEBR has already organised three calls for proposals and one more is about to start. Two of them were implemented during the first phase - in February 2018 and February 2019. The second phase has already started with a third call recently closed, and a fourth one is planned for 2021. In the first call, ten Pilot Actions were selected to test ad hoc solutions for each identified obstacle for 15 months. In the second one, thirty-three cases were appointed to receive a consultancy by legal experts with cross-border competences who analysed each particular obstacle. A total of 43 obstacles have been identified in the six thematic areas of employment, multilingualism, public (passenger) transport, health (including emergency services), institutional cooperation and e-government. A first analysis confirms that many obstacles arise as a result of the lack of coordination or the presence of extraordinarily complicated legal or administrative procedures. In other cases, uncertainties arise as to how to initiate cooperation, because of legal or administrative frameworks that do not take account of the cross-border dimension or an unfavourable division of competences, which sometimes only reside at the national level.

Possible solutions have been explored in six thematic areas relating to the type of action required to resolve the obstacle. In most cases, the solution had to be created, for example, through the introduction of new legal provisions or the development of innovative methodologies and protocols of action. For other solutions, it was only necessary to apply existing rules at European level, which had not been used hitherto for these specific cases. We also paid attention to the ECBM as an additional instrument that could facilitate cooperation at the EU's internal borders. The benefits of its possible implementation have been highlighted by the experts who analysed cases, drawing attention to the facilitation of cooperation processes if those solutions can ever be applied.

Analyses of obstacles and proposed solutions offer the basis for the knowledge gained as $b$-solutions are implemented. It has become clear that solutions cannot be enforced if political will is lacking. Another essential prerequisite is trust between actors, as well as the necessary awareness of all instruments available to facilitate collaboration between neighbours. Finally, another issue of particular importance relates to the need for a multi-level set of actors to become involved, as solutions with a local impact often require national or European policymakers. This experience is accompanied by policy recommendations that will be suggested to the competent authorities, political actors and professionals at the local, regional, national and European levels, so to raise awareness of the myriad obstacles preventing greater cooperation across borders and thus limiting the development of European integration in all territories. 


\section{New challenges and COVID-19 on top}

Currently, we are facing a critical moment for European integration. Recent years have brought a wave of Euroscepticism, nationalism and populism, garnished with fake news and partial approaches by interested groupings and organisations. At the top was Brexit, in which all the elements referred to may be found. But this European challenge has gone further: just as Brexit was gaining its definitive momentum (for the time being), COVID-19 showed up, putting Europe before its mirror.

With the implementation of $b$-solutions and regular exchanges with EU institutions, local and regional authorities and cross-border structures, we considered ourselves well-equipped to follow the last round of negotiations for the European budget for 2021-2027 and offer, if necessary, an additional set of arguments in favour of territorial cohesion. First of all, it was crucial to protect certain traditional European policies, put at risk by the emergence of new priorities. Some states were struggling to separate the harmonious development of all European territories from the need to drastically reduce the impact of such development on the environment. We clearly stated our aspiration to a new generation of European territorial cooperation programmes aimed at simplifying procedures, supporting people-to-people projects and the most vulnerable regions, coordinating and integrating various financing instruments and placing sustainable development, climate action and further digitisation at the centre of the action. In the context of these discussions, the AEBR looks small for an organisation aspiring to influence such decisions. However, it played a part within the Cohesion Alliance (CoR, 2018) - as an initiative launched in 2018 by KarlHeinz Lambertz, the former President of the European Committee of the Regions (and current President of the AEBR), now promoted by major associations of regions and municipalities, and attracting thousands of supporters. This Alliance has been vocal in demanding a post-2020 European budget geared towards a stronger, more effective, visible and accessible Cohesion Policy for all regions of the EU.

And then came the pandemic. The closing of borders more or less coincided with the $25^{\text {th }}$ anniversary of the Schengen Agreement and the $30^{\text {th }}$ anniversary of Interreg. The 'Europe without borders', which seemed to have been set in stone, had to be dismantled to control the spread of the virus. Borders were opened again from June, but new restrictions came along, and certain others were to be expected. For this reason, we were made to realise how fragile some of our achievements actually are, how much we should appreciate and take care of them, and how to keep in mind those unable to enjoy them.

All states have taken steps to combat COVID-19, but the effects of the pandemic cannot be predicted, as there is not much certainty. European public health services reacted very decisively, and citizens accepted the need for containment and protective measures, especially social distancing. Despite the circumstances during the summer and the more than probable further waves before an effective and safe vaccine is available for the whole population, the only outcome we may expect is ultimate full control over the pandemic, sooner or later. We have accepted these tremendous restrictions on our fundamental freedoms of movement because the goal is to contain the virus. However, this has caused significant inconveniences in all territories, but particularly in border regions - albeit some more than others, depending on the reality of their cross-border interrelationship. Looking at the divergent behaviours of national and other competent authorities, the restrictions on movement between countries when all internal restrictions are lifted are questionable. Many borders along which entire sectors depend essentially on the other side if they are to operate normally, and even during the confinement it was not possible to close these borders completely without some key sectors being affected very seriously. As the Central European 
Services for Cross-Border Initiatives (CESCI) said recently during the launch of another Alliance - in this case of Cross-Border Citizens': 'solidarity between Europeans now means separation between people, but we do not need to separate countries' (Alliance, 2020).

We are dealing with a virus that is still unknown in many ways, producing many asymptomatic infections that make it difficult to detect and much more to prevent for as long as vaccination campaigns are not completed. Meanwhile, containment, the management of the sick, control measures such as social distancing, and common sense, are our best arsenal. It is also true that threats of this general kind have been known about for decades. International agencies, especially the World Health Organisation (WHO) and other health institutions, think-tanks, non-government organizations, etc., have long warned of the lack of preparedness to prevent a major epidemic from becoming a pandemic (Inglesby \& Toner, 2018, September 19; NTI, 2019). Health expenditure indices have been published by the WHO (WHO, 2020) and the OECD (OECD, 2020) and a multitude of recommendations developed by specialised agencies, organisations, and experts well before COVID-19 appeared (WHO, 2009; Event 201, 2019). The EU has also regulated certain areas of particular interest, such as cross-border healthcare (through a Directive adopted in 2011; EU, 2011), yet to be fully implemented in all member states, to address the specific health needs of border citizens). But the Union also reacted when the pandemic erupted, adjusting some cross-border aspects, such as commuters in key sectors, the transport of essential products, etc., particularly in the light of measures taken unilaterally, of course by certain member states.

Among many other arguments, it has been stressed that - in the face of an assumption that we live in a global society in which the market produces and covers all our needs - the pandemic shows how Europe fails to produce enough to guarantee strategic stocks of essential medicines and healthcare materials. The need to maintain supply chains may allow us to open our eyes to the reality that states alone cannot do this. Borders need specific, coordinated management between both sides, and 'we cannot trust a global society that is too inhospitable', using the words of the opinion director of a well-known Madrid newspaper (Martínez-Bascuñán, 2020, May 17). That is why the answer is more Europe. A Europe that acts with one voice, strengthening its cohesion and identity, as well as its awareness of its place in the world. However, the EU can only publish guidelines and recommendations, since health is the exclusive responsibility of the states, being managed in some cases by the central governments and in others by the regions or municipalities. The large asymmetry between skills, service portfolios and quality of service, as well as between therapeutic approaches and other circumstances specific to cross-border environments, constitute additional difficulties to be considered. The different ways of dealing with this crisis in different countries have also been somewhat surprising. That said, it is also true that the pandemic entered each country in different ways, showing different dynamics and social patterns thanks to which the virus has spread with differing intensities.

Some countries, well equipped for various reasons, but especially as a result of lessons learned from past threats and adequate preparedness, were able to identify initial outbreaks and isolate them, controlling the spread of the virus from the outset, with a manageable impact on health systems. In other cases, the virus entered through different routes in societies whose interpersonal and intergenerational contacts are especially close. Despite very strict measures, the virus was transmitted very quickly, to an extent that put the reaction capacity of health systems at risk. And in other countries, despite the significant spread of the virus and the increasing incidence of the disease, insufficient restrictions were put in place and the effects of COVID-19 in terms of both numbers of victims, the economy, etc., are proving to be even more calamitous.

\footnotetext{
${ }^{7}$ The AEBR, the Hungarian CESCI and the French MOT (Mission Opérationnelle Transfrontalière) launched a 'European Cross-Border Citizens' Alliance' in July 2020 to promote CBC within the EU (Alliance, 2020).
} 


\section{The reaction of the EU}

The start of the crisis was devastating: very rapid growth in numbers of cases and deaths, stringent national measures, messages of rupture and harsh statements from some northern Finance Minister described as repugnant by some southern Prime Minister, maximalist positions on both sides, unilateral reactions, etc. Fortunately, the situation improved in most cases very quickly, from the earliest Eurogroup commitment to urgent measures to the more constructive and calm tone of the European Council of 23 April (compared with previous ones, and in particular that of 26 March). The budget proposal and recovery plan put on the table by the Commission were very promising, and the first reactions of the Parliament encouraging. But as usual the last word was with the Council.

We must not forget that there have been discrepancies in almost every aspect: the size of the reconstruction fund, how to finance it (each country's contribution, common indebtedness), how to distribute the aid (subsidies or credits), and its territorial and sectoral distribution. The most-affected countries in the South asked for a trillion euros, with community debt and subsidies. The 'Frugal Four' preferred a smaller fund distributed in the form of credits. But even this was considered too much by some of them. The South did not want to lose the battle of debt mutualisation and the North rejected further pressure. An intermediate solution leading to a collapse in the South was not in the interests of the North (or of the Single Market) either. And the South should not underestimate the citizens' rejection of certain measures in the North.

However, the virus has changed our lives and could accelerate the transition to a more sustainable energy model. Some want to see the pandemic and its consequences as a direct application of Ockham's razor to politics: fossil fuels damage health and worsen climate change, while clean alternatives are available, albeit undervalued and underdeveloped. There are many visions and perspectives on the changes that this pandemic will leave in our daily lives. Faced with those who call for a national retreat and the end of globalization, the German philosopher Peter Sloterdijk (2020, June 12) has called attention to the extreme interdependence that we have achieved, and defines the concept of 'co-immunism' as an individual commitment to mutual protection. In general, most reasonable messages are going in the direction of a joint effort for recovery, refusing to return to previous models of development, and tackling climate change while rebuilding the European economy. If this operation were to succeed, Europe would have taken a giant step in consolidating its legacy for upcoming generations.

\section{Discussions on the European budget}

In principle, all convinced Europeans are likely to find it rather ridiculous that the EU budget accounts for only just over $1 \%$ of the total Gross Domestic Product (GDP) of its member states. The major discussion prior to the pandemic was on whether the new 7-year MFF should achieve 1.3 or just $1.1 \%$ of EU GDP. There was a strong delay to deciding on the EU budget for the programming period 2021-2027 for various reasons, including the pandemic. In the end, despite an initial trend towards yet a further reduction in the EU budget, the emergency necessitated an extension of extraordinary support to several member states, and this was expected to have consequences for the future common budget, in terms of both size and scope. The European Council ended its Summit of 21 July (EUCO, 2020a) by agreeing on a new MFF amounting to $€ 1,074.3$ billion, with a 750 billion Recovery Fund on top of that. A Franco-German deal pushed this Fund forward in 
mid-May, when it began to look as if a first agreement was in sight. There were many pressures, particularly exerted by certain member states in the North (the 'Frugal Four'), but the MFF was just slightly reduced from $€ 1.1$ to 1.074 trillion, while keeping many features of the Council's proposal from February, with some relevant reductions, including on Interreg. Meanwhile, the Recovery Fund resisted: $€ 750$ billion for the NGEU, with a smaller proportion of grants than expected ( $€ 390$ billion to be distributed in the form of grants and $€ 360$ billion as loans, in place of the previous 500/250 proposal). Own resources are finally possible, breaking a traditional red line that even the Great Recession of 2008-2010 was not able to cross.

The first insights on how the budget and the recovery fund would look like were provided during a speech delivered by the President of the European Commission, Ursula von der Leyen, at a European Parliament Plenary Session of 13 May. Most EP political groupings endorsed this plan, and the reaction of the European Council was expected to be shaped on 19 June, while the member states or groups of them had made their counterproposals, contributions, or remarks. However, as that online Council meeting produced no results, EU leaders decided to meet physically in Brussels on 17-18 July. In the meantime, due to the need to coordinate EU institutions more closely with a view to stronger political leadership being achieved in the name of a rapid agreement, the President of the Commission called Charles Michel (President of the European Council), David Sassoli (President of the European Parliament), and Chancellor Angela Merkel (representing the German Presidency of the Council of the EU in the second half of 2020) for a mini-summit on 8 July. This was in advance of the full meeting of member states' leaders, and was intended to take stock of the negotiations, and ensure a certain further input in the direction of a deal. The leaders had seen very clearly what crossroads the EU had arrived at, and decided to set course for the fifth Juncker scenario - the one involving 'more Europe'(!) in its White paper on the Future of Europe (COM, 2017b).

Then, on 10 July the President of Council presented a new negotiation box (10/7 NegoBox), and on 14 July Commissioner Ferreira met the Cohesion Alliance. Meanwhile, some EU leaders crossed Europe several times to meet each other in the period 13-16 July, while there was also a proliferation of videoconferencing. The Summit proper finally commenced on $17 \mathrm{July}$, lasting through to the morning of 21st, and so attaining a total length shorter by just 25 minutes than the longest in EU history (the European Council convened in Nice on 7-10 December 2000).

The result can be considered quite satisfactory in terms of the total budget of the EU. Deeper cuts in the MFF have never been an option, and the 'minimum agreed Europe' actually seems quite high. The recovery package makes the budget grow enormously (at least until 2023), and the level of financial commitment has grown substantially beyond previous taboos, such as mutualised debt and new own resources. As was already mentioned, we are probably approaching a milestone in EU integration comparable with the Maastricht or Lisbon Treaties, the introduction of the Euro, or the huge EU enlargement of 2004. However, this EU budget leaves a bitter taste for various reasons.

We hope that the weight of certain major programmes will be shaped and better tuned in the last stages of negotiation, but the feelings are quite frustrating in key sectors such as health and research, with many now working against the clock to prepare an effective immunisation or to test better treatments for COVID-19 worst cases. The Interreg family also has many reasons to be worried, as do Neighbourhood and Pre-Accession stakeholders, or those expecting a stronger environmental commitment.

Some member states started to consider the use of an enhanced cooperation mechanism included in the treaties to allow a minimum of nine to pursue specific policies, while the ball 
was in the Parliament's court. The President of the EU Chamber announced immediately postsummit that some elements of the deal were not acceptable, in particular the cuts to EU-funded programmes in the MFF and the weak nature of rule-of-law conditionality. This was highlighted in a resolutions of the Parliament drafted the day after the Summit, which also asked for a stronger role of the Parliament in the governance of the recovery package, the 'emergency brake' and the approval of national programmes, among other aspects (EP, 2020, July 22). During a debate with European Council president Charles Michel on 23 July, Manfred Weber, the Group of the European People's Party (EPP Group) leader in the European Parliament, stated clearly that the budget did not look future-oriented enough, and risked being spent on national favourites. He also stressed the need to link funding with respect for EU rules and mechanisms. Iratxe García Pérez, Socialists \& Democrats Group (S\&D) leader, showed their rejection to cuts in research, Erasmus, digitisation, and humanitarian aid. Dacian Ciolos, leader of the Liberals, asked that 'European projects should not be sacrificed in favour of cuts' (EU Observer, 2020, July 24). The Parliament also insisted in the need to see a concrete and precise timeline for own resources. And the Commission would need to decide how to amend its original proposal with the agreement of EU leaders and the Parliament's remarks ${ }^{8}$.

Either way, the real work starts now. Countries receiving EU support have to give proof that deserve such solidarity, and this is a huge step forward for European integration, agreeing to the incurring of joint debt for the first time (though partially and for a limited period). Most analysts these days recall the famous Monnet's Law (Europe will be forged in crises and it will be the sum of the solutions adopted for those crises) (Monnet, 1978). Member states seem only to pool their sovereignty when forced to do so by necessity. They would only recognise in the circumstances of a crisis.

\section{Territorial cohesion and cooperation in the new financial framework}

The AEBR has been following all the negotiations since 2018 within the \#CohesionAlliance, which has organised various meetings with the Commission, including a webinar of 14 July 2020 with Commissioner Ferreira on The European Recovery Plan and its implications for EU cohesion policy, just before the 17-21 July Summit. AEBR President Ann-Sofi Backgren stressed the Commissioner that the budget for European Territorial Cooperation should be increased further. She highlighted:

(...) the need for a stronger Cohesion Policy within the new MFF; as well as for a Recovery Fund that takes account of European territories facing specific difficulties, such as border, mountain, peripheral regions, islands and other maritime regions; additional constraints like a sparse and/or aged population, brain drain, lack of infrastructure and public services; and of course key general challenges of a climatic and demographic nature, the transition to more sustainable development approaches and energy sources, optimal digitisation, and resilience in the face of global threats like COVID-19. Most border regions share many of these circumstances, and there are further difficulties relating to the growing need to coordinate diverse national regulations that might 'collide' at national boundaries (Cohesion Alliance, 2020, July 15).

A positive aspect for border regions is the consolidation of Territorial Cooperation among the EU's key policies, as part of the Cohesion Policy. The organisation of all CBC programmes at both

$\overline{8}$ This finally happened on 10 December, when the Council agreed on the Multiannual Financial Framework 20212027 and the Recovery Fund (EUCO, 2020bc). 
EU internal borders and the external frontier - with the same rules under the coordination of DG REGIO - would also seem an important step forward. The proposed further simplification of procedures and reduced number of red lines facing fund beneficiaries are further noteworthy aspects, as are possibilities opened up by the combining of financial instruments. There are more opportunities for border regions in the proposed reform programme, and additional options remain within the European Regional Development Fund (ERDF) and the European Social Fund Plus (ESF+) contexts. In this framework, we have proposed to use ITI (Territorial Investment Initiatives) and other similar instruments on a cross-border basis. However, the outcome of the Brexit final accounts, the effects of the European Green Deal, the growing role of the Sustainable Development Goals, and the priorities established by the pandemic will have to apply too. Therefore, border regions need to be prepared to implement innovative interventions by making smart use of the various instruments available.

During the negotiations on the MFF and further on with the Recovery Package, the Commission has re-confirmed several times its strength in defending the role of cohesion in the new instruments, particularly React-EU (Recovery Assistance for Cohesion and the Territories of Europe; COM, 2020a). During her presentation of this new emergency instrument on 28 May, Commissioner Ferreira confirmed that 'despite being one of the oldest EU tools, cohesion would be one of the key elements of this recovery proposal, together with conversion and reforms' (Euractiv, 2020, May 28). Cohesion looks crucial when one considers the different starting points of EU territories, and their different capacities to respond to new challenges (including those already known about such as climate change, as well as new ones, such as the effects of the current pandemic). React-EU is a temporary emergency instrument given effect through to 2022 only, with this topping current Structural Funding with an additional $€ 47.5$ billion.

The rules will be the current ones, but with greater flexibility (measures activated during the pandemic, such as possible transfers between programmes, objectives and regions, will remain). The allocation of funds will consider 'the severity of the economic and social impacts of the crisis, including the level of youth unemployment and the relative prosperity of every Member State' (Euractiv, 2020, May 28). 'It is a massive increase that is completely necessary if we see the extra effort that is required', said the Commissioner to Members of Parliament. 'EU cohesion policy was one of the first instruments the Commission used to react to the COVID-19 outbreak', and flexibility will remain a key element in the new regional policy, which will also include a 'fully-fledged crisis-response mechanism' to respond to potential future crises (Euractiv, 2020, May 28).

The chair of the European Parliament's Committee on Regional Development, Younous Omarjee, highlighted the manner in which 'cohesion policy was the only Union policy capable of responding urgently to the crisis to help the hospital sector, SMEs and employees.' He also stressed the importance of the instrument in supporting territories 'when they are hit by an unprecedented explosion. (...) Cohesion policy has helped build Europe, and it will help rebuild it' (Euractiv, 2020, May 28).

There are still some remarks from border regions regarding the allocation method for the European territorial cooperation goal. Some of the criteria are based on the population living within $25 \mathrm{~km}$ of a border, though this can lead to the discrimination of border territories with a lower and sparse population. Co-financing rates were also a matter of discussion, initially proposed not to be higher than $70 \%$ for CBC programmes; but they were finally established at a level of $80 \%, 85 \%$ for outermost territories, and the possibility of higher co-financing rates for external (Neighbourhood and Pre-Accession) CBC programmes. 


\section{The importance of external borders}

By the way, the severity of the pandemic and the internal debates in the EU cannot distract us from paying attention to external borders. The growing importance of $C B C$ in European policies can be decisive for a deeper development of integration, and this also applies to external border regions. There are already European policies that have incorporated a cross-border logic, such as health and transport. Others, such as employment, are moving in that direction, and both e-government and multilingualism already have a cross-border component in their genome. All these developments should also benefit external border programmes.

A long-pending issue for the European border regions was the management of programmes at the external borders by departments different from those implementing Interreg programmes, following different logics and systems. Their coordination under a single roof is already a reality for both the Instrument for Pre-Accession Assistance (IPA-CBC) programmes since 2019 and the Neighbourhood Instrument (ENI-CBC) programmes since 2020. It is very good news that these programmes continue to form an element of European external action policies linked even more closely with international cooperation and development from a political point of view; as well as with other territorial cooperation programmes from the point of view of management. This is an interesting engineering exercise that we have welcomed and supported.

\section{Small-project funds and people-to-people projects}

An aspect often forgotten, but very effective for $C B C$, entails the small-project funds based on people-to-people actions. They are very useful for incorporating sectors of the population that traditionally do not participate in more-major European projects, mostly reserved for public bodies of a certain size, large organisations, international consultants, etc. These funds can finance minor interventions not demanding large-scale infrastructure, a huge level of co-financing or pre-financing. They are very simple to prepare and justify, and they allow small environmental organisations, neighbourhood associations, parents, sports, social, religious, voluntary clubs, etc. to join CBC, thereby making it much more inclusive.

The experience of several Central European Euroregions when it comes to the management of these funds over several programming periods has allowed very valuable lessons to be drawn, even though there remain certain controversies between the managers of the funds and the European Commission when it comes to the administration costs of these funds, their thematic concentration, or the type of organisations eligible for their management. Some of their most obvious benefits are the large doses of trust generated across (for example) the German-Polish border, by projects managed by the Pomerania, Europa Pro-Viadrina, Spree-Neiße-Bober and Neiße-NisaNysa Euroregions. The experience with the management of small-project funds is also a major source of diversification in the areas of expertise of a given Euroregion, and it allows for a focus on areas from which cooperation is often lacking (rural areas with a very sparse population, remote territories, etc.). Its combination with other rural-development measures (tourism, gastronomy, new technologies applied to agriculture, ecological transition, etc.) could offer optimal inspiration for other territories. 


\section{European Groupings of Territorial Cooperation (EGTCs)}

As noted before, the creation of a European legal instrument to facilitate $\mathrm{CBC}$ appeared as a pressing need in the late 1990s, especially when CBC became more complex and required the existence of entities with the capacity to provide cross-border services, employ public officials and manage public and private funds across borders, etc. In the early years of this millennium, the AEBR was very active in preparing the first studies on this instrument for the Parliament and the Commission (AEBR, 2004). Finally, the adoption of its Regulation in 2006 (EU, 2006) and its subsequent amendment in 2013 (EU, 2013) allowed for a legal framework facilitating CBC in many ways.

There are currently 77 EGTCs registered at the Committee of the Regions' EGTCs Platform (CoR, 2020), with some of them generalists and other specialised. Although some exist on paper only, most render a great service to $\mathrm{CBC}$, facilitating the management of complex Euroregions involving more than two countries, such as the Meuse-Rhine Euregion (BE/DE/NL) or the so-called Greater Region (BE/DE/FR/LU); and very active ones, such as the Pyrenees-Mediterranean Euroregion (ES/FR). They also represent a perfect framework through which to develop genuine $\mathrm{CBC}$ between regional authorities, as with the Galicia-Norte de Portugal EGTC); to provide all kind of services to small municipalities (as with the EGTC of the PAMINA Eurodistrict (FR/DE) or DueroDouro (ES/PT); to implement a public service, as with the Cerdanya Cross-Border Hospital (ES/FR) in the Pyrenees; or to strengthen cross-border urban processes, as with Lille-Kortrijk-Tournai (FR/BE) or the Guadiana Eurocity (ES/PT).

Attention must be paid to yet-further possibilities among the EGTCs, since they can be created not only for $\mathrm{CBC}$ but also for transnational and interregional cooperation, as in the case of the International Alliance for the Rhine-Alpine Corridor (BE/CH/FR/DE/IT/NL). Main disadvantages are the efforts needed to create a new structure in terms of legal provisions, infrastructure, personnel, services, etc. However, they provide a perfect platform for resolving many cross-border issues, managing larger or smaller programmes and - as indicated above - providing cross-border services in a coordinated manner.

\section{Brief conclusion}

There are many old and new reasons for preserving and even strengthening European territorial cooperation, especially under current circumstances, when there is a risk of new border closures, and of certain restrictions remaining in place even after the pandemic is over. Furthermore, there is a certain retrogression in European integration already detectable some time ago in various EU member states, well before the pandemic. These first signs of deterioration could be felt at the borders, and it is also at the borders that the strongest steps can be taken to counteract this erosion of the European construct. As underlined at the Annual Conference of our Association in Dresden on 24 October 2019:

(...) if, after World Wars and their disasters, we were able to heal our wounds, of which those scars of history that we call borders remain, it is at these same borders that our greatest wealth must be built, although we do not always use it. That solid integrating material, although intangible, has made humanity able to reach its greatest levels of development. We are not referring to material wealth, but mutual trust (Guillermo Ramírez, 2019). 
Thus, at a time when we were still unsuspecting as regards the threat looming over us, we were already aware that these were times needing great decisions - in which we had to answer the following question: are we willing to continue fostering rampant mistrust, fear and bitterness, and to risk ending up locked up within our own borders? Or should we rather make further progress in building an ever-increasing space of democracy, prosperity and sustainability?

\section{References}

AEBR (2004). Towards a new community legal instrument facilitating public law based trans-European co-operation among territorial authorities in the European Union. Summary Position Paper. Gronau: Association of European Border Regions.

AEBR (2017). b-solutions project. Retrieved from https://www.b-solutionsproject.com/

AEBR (2020a). b-solutions: Solving Border Obstacles. A Compendium of 43 Cases. Luxembourg: Publications Office of the European Union. https://doi.org/10.2776/239689

AEBR (2020b). Annex. b-solutions: Solving Border Obstacles. A Compendium of 43 Cases. Luxembourg: Publications Office of the European Union. https://doi.org/10.2776/36819

AEBR (2020c, May 19). Newsletter Spring 2020. "Covid-19" Special Edition. Association of European Border Regions. Retrieved from https://us9.campaign-archive.com/?u=1ac1f186b0d56a48c4d7dfc03\&id $=2972 \mathrm{e} 850 \mathrm{~d} 2$

AEBR (2020d, August 3). Insight \#2. Association of European Border Regions. Retrieved from https:// us9.campaign-archive.com/?u=1ac1f186b0d56a48c4d7dfc03\&id=b36010cdaa

Alliance (2020). European Cross-Border Citizens' Alliance. Borders at the Heart of Europe of Tomorrow. Association of European Border Regions, Central European Service for Cross-border Initiatives, Mission Opérationnelle Transfrontalière. Retrieved from http://www.espaces-transfrontaliers.org/en/ activites-ue/european-cross-border-citizens-alliance/

Britannica (2020). Berlin West Africa Conference. Britannica. Retrieved from https://www.britannica. com/event/Berlin-West-Africa-Conference

Cebrián, J. L., \& González, F. (2001). El futuro ya no es lo que era - una conversación [The future is no longer what it used to be]. Madrid: Aguilar.

Cohesion Alliance (2020, July 15). Europe's recovery will fail without a strong cohesion policy and a real partnership among EU, national, regional and local actors. European Committee of the Regions. Retrieved from: https://cor.europa.eu/en/news/Pages/Europe-recovery-will-fail-without-strongcohesion.aspx

COM (2015-2017). Cross-border Review. Retrieved from https://ec.europa.eu/regional_policy/en/policy/cooperation/european-territorial/cross-border/review/

COM (2017a). Boosting Growth and Cohesion in EU Border Regions. Communication from the Commission to the European Parliament and the Council of 29 September 2017, COM(2017)0534 final.

COM (2017b). White Paper on the Future of Europe. Reflections and scenarios for the EU27 by 2025. European Commission. COM(2017)2025.

COM (2018). Proposal for a Regulation of the European Parliament and of the Council on a mechanism to resolve legal and administrative obstacles in a cross-border context. European Commission, $\operatorname{COM}(2018) 373$ final.

COM (2020a). Proposal for a Regulation of the European parliament and of the Council amending Regulation (EU) No 1303/2013 as regards exceptional additional resources and implementing arrangements under the Investment for growth and jobs goal to provide assistance for fostering crisis repair in the context of the COVID-19 pandemic and preparing a green, digital and resilient recovery of the economy (REACT-EU). European Commission, COM(2020) 451 final.

COM (2020b). Commission welcomes the political agreement on the Interreg Regulation. Retrieved from https://ec.europa.eu/regional_policy/en/newsroom/news/2020/12/12-02-2020-commission-welcomes-the-political-agreement-on-the-interreg-regulation 
COM (2020c). Interreg A - Cross-border cooperation. Retrieved from https://ec.europa.eu/regional_policy/en/policy/cooperation/european-territorial/cross-border/\#8

CoR (2018). The Cohesion Alliance. European Committee of the Regions. Retrieved from https://cor. europa.eu/en/engage/Pages/cohesion-alliance.aspx

CoR (2020). Register of European Groupings of Territorial Cooperation. Retrieved from https://portal.cor. europa.eu/egtc/CoRActivities/Pages/welcome.aspx

CoE (1980). European Outline Convention on Trans-Frontier Cooperation between Territorial Communities or Authorities. Treaty No. 106 signed by the Council of Europe's Committee of Ministers in Madrid on 21 May 1980 and entered into force on 22 December 1981. Retrieved from https://www. coe.int/en/web/conventions/full-list/-/conventions/treaty/106

EC (1990). Notice C(90) 1562/3 to the Member States, laying down guidelines for operational programmes which Member States are invited to establish in the framework of a Community initiative concerning border areas (Interreg). European Communities, 90/C 215/04.

EC (1992). Treaty on European Union, signed at Maastricht on 7 February 1992. European Communities, 92/C 191/01.

EP (2020, July 22). Motion for a Resolution to wind up the debate on the statements by the European Council and the Commission pursuant to Rule 132(2) of the Rules of Procedure on the conclusions of the extraordinary European Council meeting of 17-21 July 2020. 2020/2732 (RSP).

EU (2006). Regulation (EU) No 1082/2006 of the European Parliament and of the Council of 5 July 2006 on a European grouping of territorial cooperation (EGTC). Official Journal of the European Union, $\mathrm{L}$ 210/19-24.

EU (2011). Directive 2011/24/EU of the European Parliament and of the Council of 9 March 2011 on the application of patients' rights in cross-border healthcare. Official Journal of the European Union, $\mathrm{L}$ 88/45-65.

EU (2013). Regulation (EU) No 1302/2013 of the European Parliament and of the Council of 17 December 2013 amending Regulation (EC) No 1082/2006 on a European grouping of territorial cooperation (EGTC) as regards the clarification, simplification and improvement of the establishment and functioning of such groupings. Official Journal of the European Union, L 347/303-319.

EUCO (2020a). Special meeting of the European Council on 17, 18, 19, 20 and 21 July 2020 -Conclusions. European Council, EUCO 10/20, CO EUR 8 CONCL 4.

EUCO (2020b). Council Regulation (EU, Euratom) 2020/2093 of 17 December 2020 laying down the multiannual financial framework for the years 2021 to 2027. Official Journal of the European Union L 433 I/11-22, 22 December 2020.

EUCO (2020c). Council Regulation (EU, Euratom) 2020/2094 of 14 December 2020 establishing a European Union Recovery Instrument to support the recovery in the aftermath of the COVID-19 crisis. Official Journal of the European Union L 433 I/23-27, 22 December 2020.

EU Observer (2020, July 24). Top EU officials urge MEPs give quick budget-deal approval. EU Observer. Retrieved from https://euobserver.com/economic/149020

Euractiv (2020, May 28). Cohesion becomes central to EU recovery package. Euractiv. Retrieved from https://www.euractiv.com/section/economy-jobs/news/cohesion-becomes-central-to-eu-recovery-package/

Event 201 (2019). Public-private cooperation for pandemic preparedness and response. A call to action. Event 201. Johns Hopkins Center for Health Security, World Economic Forum and the Bill and Melinda Gates Foundation. Retrieved from https://www.centerforhealthsecurity.org/event201/ recommendations.html

Guillermo Ramírez, M. (2019). Introduction to the panel on Trust Building. AEBR Annual Conference 2019, Dresden City Hall, 24 October 2019.

Guillermo Ramírez, M. (2020). Europe is integrated within its borders. Newsletter of the Iberian-American and European Academy of Yuste Foundation, 6. Retrieved from https://www.fundacionyuste. org/wp-content/uploads/2020/06/02-TRIBUNA-ABIERTA-MartinvGuillermo-B06-v-in.pdf

Inglesby, T., \& Toner, E. (2018, September 19). Opinion: Our lack of pandemic preparedness could prove deadly. The Washington Post. Retrieved from https://www.washingtonpost.com/opinions/ our-lack-of-pandemic-preparedness-could-prove-deadly/2018/09/19/0d7b235c-b13e-11e8-a20b5f4f84429666_story.html 
Martínez-Bascuñán, M. (2020, May 17). Globalización de geometría variable. El País. Retrieved from https://elpais.com/opinion/2020-05-16/globalizacion-de-geometria-variable.html

Monnet, J. (1978). Memoirs. Garden City, NY: Doubleday \& Company. Retrieved from https://archive. org/details/MonnetJeanMemoirs/mode/2up

NTI (2019). Global Health Security Index. Building Collective Action and Accountability. Baltimore: Nuclear Threat Initiative, Johns Hopkins Bloomberg School of Public Health. Retrieved from https:// www.ghsindex.org/wp-content/uploads/2019/10/2019-Global-Health-Security-Index.pdf

OECD (2020). Health Expenditure. Organisation for Economic Cooperation and Development. Retrieved from https://www.oecd.org/health/health-systems/health-expenditure.htm

Sloterdijk, P. (2020, June 12). Co-Immunism in the age of Pandemics and Climate Change. German philosopher Peter Sloterdijk speaks with Noema's editor-in-chief, Nathan Gardels. Noema Magazine, Berggruen Institute. Retrieved from https://www.noemamag.com/co-immunism-an-ethos-forour-age-of-climate-change/

TA2030 (2020). Territorial Agenda 2030. A future for all places. Adopted at the Informal meeting of Ministers responsible for Spatial Planning and Territorial Development and/or Territorial Cohesion, 1 December 2020, Leipzig. Retrieved from https://territorialagenda.eu/home.html

WHO (2009). Recommendations for Good Practice in Pandemic Preparedness. Identified through evaluation of the response to pandemic (H1N1) 2009. Copenhagen: World Health Organisation Regional Office for Europe. Retrieved from https://www.euro.who.int/_data/assets/ pdf_file/0017/128060/e94534.pdf

WHO (2020). Global Health Expenditure Database. World Health Organisation. Retrieved from https:// apps.who.int/nha/database/ 